\title{
What is expected of higher education graduates in the 21st century?
}

Citation for published version (APA):

Humburg, M., \& van der Velden, R. K. W. (2013). What is expected of higher education graduates in the 21st century? ROA. ROA Research Memoranda No. 013 https://doi.org/10.26481/umaror.2013013

Document status and date:

Published: 01/01/2013

DOI:

10.26481/umaror.2013013

Document Version:

Publisher's PDF, also known as Version of record

\section{Please check the document version of this publication:}

- A submitted manuscript is the version of the article upon submission and before peer-review. There can be important differences between the submitted version and the official published version of record.

People interested in the research are advised to contact the author for the final version of the publication, or visit the DOI to the publisher's website.

- The final author version and the galley proof are versions of the publication after peer review.

- The final published version features the final layout of the paper including the volume, issue and page numbers.

Link to publication

\footnotetext{
General rights rights.

- You may freely distribute the URL identifying the publication in the public portal. please follow below link for the End User Agreement:

www.umlib.nl/taverne-license

Take down policy

If you believe that this document breaches copyright please contact us at:

repository@maastrichtuniversity.nl

providing details and we will investigate your claim.
}

Copyright and moral rights for the publications made accessible in the public portal are retained by the authors and/or other copyright owners and it is a condition of accessing publications that users recognise and abide by the legal requirements associated with these

- Users may download and print one copy of any publication from the public portal for the purpose of private study or research.

- You may not further distribute the material or use it for any profit-making activity or commercial gain

If the publication is distributed under the terms of Article $25 \mathrm{fa}$ of the Dutch Copyright Act, indicated by the "Taverne" license above, 
Maastricht University

Research Centre for Education and the Labour Market | ROA

\section{What is expected of higher education graduates in the 21st century?}

Martin Humburg

Rolf van der Velden

\section{ROA Research Memorandum}

ROA-RM-2013/13

Research Centre for Education and the Labour Market Maastricht University

P.O. Box 616, 6200 MD Maastricht, The Netherlands

$\mathrm{T}+31433883647 \mathrm{~F}+31433884914$

secretary-roa-sbe@maastrichtuniversity.nl www.roa.nl 


\title{
What is expected of higher education graduates in the 21st century?
}

\author{
Martin Humburg \\ Rolf van der Velden
}

ROA-RM-2013/13*

July 2013

Research Centre for Education and the Labour Market

Maastricht University

P.O. Box 616, 6200 MD Maastricht, The Netherlands

$\mathrm{T}+31433883647 \mathrm{~F}+31433884914$

secretary-roa-sbe@maastrichtuniversity.nl

www.roa.nl

\footnotetext{
* The ROA Research Memorandum Series was created in order to make research results available for discussion, before those results are submitted for publication in journals.
} 


\section{Abstract}

\section{What is expected of higher education graduates in the 21st century?**}

In this paper, we reflect on the skills higher education graduates are expected to have in today's economy and the role of higher education in equipping graduates with these skills. First, we identify 6 trends which form the basis of the changing role of graduates in economic life. These trends are the knowledge society, increasing uncertainty, the ICT revolution, high performance workplaces, globalization, and the change of the economic structure. By changing the nature and range of tasks graduates are expected to fulfil in today's economy, we argue that these trends generate new and intensify traditional skill demands, which we summarize as professional expertise, flexibility, innovation and knowledge management, mobilization of human resources, international orientation, and entrepreneurship. Second, we draw out some key issues concerning the role of higher education institutions in equipping graduates with these skills.

JEL classification: I21, 125, 128, J24

Keywords: education, labour market, skills

Martin Humburg

ROA

P.O. Box 616

NL-6200 MD Maastricht

The Netherlands

m.humburg@maastrichtuniversity.nl
Rolf van der Velden

ROA

P.O. Box 616

NL-6200 MD Maastricht

The Netherlands

r.vandervelden@maastrichtuniversity.nl

** The authors would like to thank John Buchanan, Jim Allen and Didier Fouarge as well as the participants of the Department of Education Public Seminar at the University of Oxford for valuable comments to an earlier version of this paper. 


\section{Introduction}

Expectations towards higher education institutions and their graduates have always been high. For centuries, universities have been the place where higher order knowledge and skills have been developed, refined and nurtured. Never before, however, have expectations towards higher education and its graduates been so strongly expressed and explicitly defined - in particular by employers.

This paper examines the skill set graduates are increasingly expected to possess, and the role played by and increasingly expected of higher education in developing them. As we focus on graduates, we also focus on graduate skills. This means that we leave basic skills (basic levels of skills like numeracy, literacy, computer skills) out of the analysis, taking them, in a way, for granted.

We identify 6 trends which form the basis of the changing role of graduates in economic life. These trends are the knowledge society, increasing uncertainty, the ICT revolution, high performance workplaces, globalization, and the change of the economic structure. By changing the nature and range of tasks graduates are expected to fulfil in today's economy, these trends generate new and intensify traditional skill demands, which we summarize as professional expertise, flexibility, innovation and knowledge management, mobilization of human resources, international orientation, and entrepreneurship.

We introduce these 6 trends knowing that there is no consensus among researchers on how many independent trends there are, let alone how to name and define them. We also recognize that in reality these trends do not stand isolated but are strongly interlinked, with the ICT revolution being the main driver of the others. However, we are convinced that the categorization of trends and resulting skill demands we present here serve the purpose of this paper best. They should be seen as a useful tool to examine what is expected of graduates in the $21^{\text {st }}$ century, and what are the drivers of these skill demands.

In the next section we elaborate the 6 trends and related skill demands. We then discuss some implications for the role of higher education and distil some key insights into how higher education can position itself in skill formation today. The paper ends with some concluding remarks. 


\section{The trends and related skills}

\subsection{The knowledge society and professional expertise}

\section{The knowledge society}

In developed nations, the $20^{\text {th }}$ century has been marked by a transition from an industrial society, characterized by mass production, to a post-industrial one, in which the service sector takes on a prominent role and knowledge becomes a valued form of capital. Bell (1999), who coined and brought forward the term "post-industrial society" in the 1970s, emphasizes the role played by theoretical knowledge in this type of society, particularly as the source of innovation and policy formulation. For Bills (2004, p.100) "the primacy of theoretical knowledge, even more than the shift from goods to services, or the computerization of the workplace, or any trend toward meritocratic selection, defines the post-industrial society." The transition from a fabricating to a knowledge society has been facilitated by two (other) major trends: globalization and rapid technological change. It is now possible to generate and to gather vast amounts of data, process them into relevant information and communicate them to recipients for decision making. For businesses, knowledge has become a major ingredient in gaining and sustaining competitive advantage (Wickramasinghe and Von Lubitz, 2007), and on a more general level this applies to nations, too. The emergence of the knowledge society increases the demand for knowledge workers (Reich, 1992), whose tasks are complex, non-repetitive and non-routine, and can therefore not be replaced by rulebased information and communication technology (ICT). The demands on knowledge workers are extensive. Clearly, credentialed and cognitively skilled individuals employed in the most informationintense sectors of society are the winners of these changes (Hage and Powers, 1992).

\section{Professional Expertise}

In order to prosper in the knowledge society, graduates need to be equipped with the skills necessary to fulfil tasks which are at the heart of knowledge work. This entails: 1) a specific body of knowledge (the knowledge and skills needed to solve occupation-specific problems, 2) the ability to apply expert thinking, and 3) general academic skills (e.g. analytical thinking, reflectiveness, and the ability to see the limitations of one's own discipline).

In contrast to the application of more pragmatic and contextual knowledge, knowledge work entails unstructured decision making. Unstructured decisions concern important, novel, non-routine problems for which no established procedure exists for how to solve them. Levy (2010) calls "expert 
thinking" a collection of specific solution methods which vary with the problem at hand. It does not only entail a specific body of knowledge but also the ability to apply expert thinking. Becoming an expert, however, is time and learning intensive. The important difference between a young professional or recent graduate and an expert is that the expert can deviate from routine solution methods. Here, broad academic skills, such as analytical thinking and reflectiveness, help the expert to know when doing so is appropriate. According to OECD's Definition and Selection of Key Competencies (DeSeCo) project, reflectiveness is the ability of individuals to become the object of their thoughts (Rychen and Salganik, 2003). Thinking reflectively allows individuals to relate a solution method to other aspects of their experiences and to subsequently adapt it to novel problems. It also allows them to see the limitations of their own discipline and to take other perspectives into account. This is especially important as a substantial proportion of today's innovations takes place at the cross-section of disciplines and knowledge workers have to successfully work in teams of professionals from different disciplines. A certain amount of interdisciplinary knowledge supports this process.

All these aspects of professional expertise taken together - a body of knowledge, expert thinking, and broad academic skills - are what enables knowledge workers to adequately execute their profession. However, it requires considerable time and investment to establish and maintain a collection of theoretical knowledge and specific solution methods often complemented by learning how to use professional tools (think of drills for dentists or computer-aided design tools for engineers). The time necessary to become an expert in a job is usually estimated to be 5-10 years (Hayes, 1981; Ericsson and Crutcher, 1990).

\subsection{Increasing uncertainty and flexibility}

Increasing uncertainty

It is widely recognized that the last 40 years have seen a significant shift of the risks and costs associated with economic activity from institutional shareholders and their agents to smaller businesses and workers. While some authors interpret this shift as a gradual return to equilibrium after the exceptionally long boom of the late 1940's, the 1950's and the early 1960's ${ }^{1}$, others see over-capacity and intensifying international competition in manufacturing, as well as the emergence of financialization and excess liquidity at the core of this development (Brenner, 2006; Froud, Johal, Leaver and Williams, 2006). Brenner, for example, argues that, confronted with international competition of new lower cost market entrants, firms have been successful in putting pressure on

1. For an overview of interpretations of postwar growth see Crafts and Toniolo (1996). 
labour in order to maintain their rate of profitability in otherwise unprofitable production lines. Froud et al. (2006) do not find evidence for labour shedding in large firms in the US and the UK in the 1980 's and 1990's, yet they show that capital markets use the rhetoric of shareholder value to pressure managers to hold down fixed labour costs and to restructure their firms in times of economic difficulties. At the basic level, this has facilitated the growth of the share of workers with fixed-term contracts and workers employed through temporary employment agencies. Against this background, there is evidence that these risk and costs have been passed down unequally onto two main groups of workers. On the one hand, there is a trend towards the emergence of a highly valued core labour force of knowledge workers. This core labour force is increasingly employed in flexible and fluidly defined work settings. Workers are allocated to tasks according to market demand and might even be expected to do a variety of minimally overlapping jobs during their life time, possibly by means of re-training. In these work settings, flexibility is functional and internal. The counterpart of this core labour force is a pool of part-timers, temporary workers, self-employed and highturnover workers, which has been growing in numbers in most developed economies over the last decades (Castells, 1996) and whose share of the work force approaches $40 \%$ e.g. in the UK. The increasing incidence of non-standard work arrangements led Castells to suggest that the "full time, career-seeking, long-term salaried employee is an endangered species" (Castells, 1996).

Although flexibility is increasingly demanded by employers, skills related to flexibility, such as the ability to rapidly acquire new knowledge, are not necessarily rewarded. Allen and Van der Velden (2011) show that professional expertise - not flexibility related skills - is by far the skill that has the strongest positive relationship with earnings and the probability to be employed. If, as Castells hypothesizes, the labour force is indeed composed of a highly valued core of knowledge workers and a pool of flexible "on demand" workers, professional expertise seems to be the entry ticket to the core group.

The emergence of a system which increasingly combines a core labour force with externally flexible workers is often explained by employers' need to react to economic shocks in highly regulated countries. When wages are rigid, firms hire temporary workers or offer workers fixed-term contracts to hedge market uncertainty (DiPrete, Goux, Maurin and Quesnel-Vallee, 2006). Workers with flexible contractual arrangements can then easily be let go when business gets worse. However, flexibility can also relate to new flexible production processes involving networks. Different economic agents organize and come together in networks for specific projects, just to get together in other constellations for the next project. 
Schmid (1998) argues that, next to economic forces, social differentiation and the need to deal with demographic challenges adds to this flexibilization trend. On the one hand, individuals may decide to temporarily reduce working hours or exit the labour force to care for children or parents, or in general embrace non-standard work arrangements in order to find a balance between private and working life that corresponds better to their preferences. On the other hand, employers may offer flexible work arrangements in tight labour markets in order to motivate individuals to participate in the labour force.

As a result of the changing relationship between employers and workers, the latter experience an increasing number of labour market transitions, be they voluntary or involuntary. According to Schmid (1998) it is the responsibility of governments to take account of these developments by combining labour market flexibility and social security in a way that facilitates the creation of transitional labour markets. He distinguishes five types of transitions: (1) transitions between different kinds of employment (transitions between dependent and self-employment, part-time and full-time employment, or fixed-term and more permanent employment relationships), (2) transitions between unemployment and employment, (3) transitions between education and training and employment, (4) transitions between private and labour market activity, (5) and transitions between employment and retirement. In the past the transition from education to employment was the major - and for many the only - transition, leaving aside the transition to retirement.

While the state establishes the framework for transitional labour markets, it is the individual workers who have to master these transitions. Today, making one of these transitions is becoming more frequent and common for individuals. Consequently, individuals have to be equipped with the skills necessary to master the level of external flexibility that is expected of them or that they think is most appropriate for their preferred work-life balance.

Of course, graduates - the group of workers we are focussing on in this paper - have a higher chance of belonging to the valued core labour force than medium or low educated workers (DiPrete et al., 2006). Moreover, further research has to determine whether flexibility is part of a life-long boundaryless career (Stone, 2006) or just a temporary phenomenon in the early stages of the career (Allen, Coenen and Humburg, 2011). At the least, also for graduates becoming a member of this valued core might take a while and therefore they need to be prepared to successfully master periods of increased uncertainty. 
Flexibility

Flexibility demands a lot from individuals. To remain flexible means to expect the unexpected, to stay employable, to reskill and retrain, to leave familiar work environments and to get acquainted with new tasks. For some, it might even mean losing expert status. Irrespective of these responsibilities, flexible work arrangements, such as part time work or occasional work, potentially offer workers the opportunity to find a better balance between work and private life. This argument, however, has to be taken with a pinch of salt, as it presupposes a fair amount of voluntariness in belonging to the pool of flexible workers.

The following skills contribute to flexibility: 1 . The ability to deal with changes and uncertainty; 2 . The ability to learn new things and 3. Employability skills (e.g. the willingness to invest in further education and training and the ability to plan and take responsibility for one's own career).

Above all, individuals need to be able to deal with changes and uncertainty. They have to incorporate uncertainty and the need to be flexible into their life plans and personal projects. In addition, flexibility is often equated with general skills such as the ability to learn new things. Finally flexible workers are increasingly responsible for their own employability. This includes making plans and setting aside time and resources for further training and life-long learning. Being employable demands a substantial level of transition skills. Although flexicurity - the combination of flexibility and security - is mainly seen as a challenge to be resolved at the national level by introducing appropriate labour market institutions (Schmid, 1998; Muffels, 2008), successfully mastering the many possible transitions between education and training and employment, different forms of employment, employment and unemployment, and labour market activity and private activity requires substantial knowledge on how the system works.

\subsection{The ICT revolution and innovation and knowledge management}

\section{The ICT revolution}

Of the six trends we are identifying, technological change is without doubt the one that is interlinked the most with the other trends. Technological change and especially the predominance of ICT is the driving force behind the emergence of the knowledge society, it has changed markets and contributes to increased levels of market uncertainty, it facilitates and necessitates the emergence of high performance workplaces, and it is a main driver of the globalization and changes in the economic structure. 
Hage and Powers (1992) draw a distinction between instruments and other machines which are primarily used in production processes. While instruments increase the number of tasks being performed, most machines simply replace labour. ICT can assume both forms and there is widespread consensus that the introduction of ICT into workplaces is skill biased - that it favours higher skilled workers. For repetitive, routine tasks - often performed by low and medium skilled workers - ICT can be seen as labour replacing. ICT is faster and cheaper than people in performing these tasks. With regard to knowledge work and professional expertise, however, ICT is mostly instrumental and complements labour (Levy, 2010). For example, computer software may speed up the process of designing and drafting structures, and through 3D applications may help architects and customers to get a better idea of what a structure will look like once it is built. Software might even be able to assist with important calculations, generate alternatives or produce statistics. Yet, it does not change the fact that, in the end, the architect is masterminding the building, adjusts it to the preferences of the customer, integrates it into its surroundings, comes up with innovative features, and, ideally, gives it a "soul". Besides being a complement to (mostly skilled) labour, instruments in the form of upgraded equipment make job tasks more complex (Hage and Powers, 1992). The tendency that higher skilled individuals are better suited to use new technologies is therefore often seen as another source of skill bias (Caroli and Van Reenen, 2001; Hujer, Caliendo and Radic, 2002; Greenan, 2003). Organizations in technology rich environments might prefer highly skilled workers as they have higher digital competence and lower training costs.

According to a competing view, the adoption of new technologies by organizations is not exogenous, but a reaction to a large supply of highly skilled workers. Proponents of the endogenous skill biased technological change hypothesis argue that the expansion of higher education in the second half of the $20^{\text {th }}$ century produced a large stock of highly skilled workers, and that this in turn induced the development of new technologies directed at complementing the highly skilled in order to increase productivity and profits (Acemoglu, 1998). A highly skilled workforce may therefore have created its own demand.

Whatever the underlying causal direction of this development, the introduction of ICT has revolutionized the way data and knowledge is generated and diffused. There is today an unprecedented range of resources easily available. In the $21^{\text {st }}$ century, the challenge is not to access knowledge, but to manage, integrate and evaluate it. In this regard, graduates play a crucial role within organizations. 


\section{Innovation and knowledge management}

The ICT revolution does not only impact the skills that are directly related to it, but changes the nature and content of all other skills as well. It is hard to conceive of any professional skill that is not affected by ICT. Also so-called 'soft' skills like communication skills have significantly changed in character due to the ICT revolution. And even the most basic skills like literacy and numeracy have been impacted by ICT (OECD, 2012). Although we recognize this broad impact of ICT on all types of skills, we will concentrate here on the skills that are supposed to be more directly related to innovation and knowledge management.

ICT has important implications with regard to the skills necessary to manage knowledge in a way that supports and facilitates innovation. In today's workplaces, innovation and knowledge management are strongly related to ICT skills. The concept of ICT skills, however, is very broad. Van Dijk (2005) distinguishes between operational ICT skills (skills directly related to the development and application of ICT hardware and software), ICT information skills (skills related to searching, selecting and processing information on computers, the internet and other ICT media), and strategic ICT skills (skills related to using ICT to achieve specific or more general goals). Van Dijk's distinction quite clearly extracts the ICT skill dimensions that are of particular importance to the tasks of knowledge workers. These relate primarily to the substantial information skills and strategic ICT skills which knowledge workers require for the purpose of innovation.

Raw data and random information have no value for decision making unless filtered and put into context. Whereas in the past individuals spent considerable amounts of time searching for scarce information, for the first time in history, the predominance of ICT makes for an abundance of data to be readily accessed. Today's challenges do not lie in information gathering, but in establishing a common understanding of information (Levy, 2010). The ability to rapidly separate signals from noise is therefore not novel as a valuable capability in degree, but in type (Dede, 2010).

Filtering information is by no means limited to separating signals from noise. It also involves evaluating content with regard to its reliability and credibility (OECD, 2012). In sum, successful knowledge management requires workers to use tools interactively, encompassing using language, symbols and text; using knowledge and information; and using technology (Rychen and Salganik, 2003).

The following skills are important components of innovation and knowledge management: 1 . Innovative/creative skills (the ability to come up with new ideas or the ability to approach problems from a different angle; 2. Network, information and strategic ICT skills and 3. Implementation skills. 
Organizations' competitiveness is to a large extent based on their capacity to introduce entirely new products or processes, or to substantially improve existing ones. Today, we are far away from knowing what the necessary and sufficient conditions for innovation are, but the discussion about what facilitates it is lively. The availability of knowledge workers with good innovative and creative skills who have the ability to come up with new ideas or the ability to approach problems from a different angle is of course a major ingredient. But that is not enough. Processed, well managed and systematically communicated information is crucial to organizations' innovative capabilities. It has been suggested that organizations' innovative capacity depends on diffusion of knowledge to a broad range of key individuals within them (OECD/Eurostat, 2005). Knowledge workers therefore often are assigned the role of receptors and distributors of expert information. This includes the information and strategic ICT skills to remain alert to new developments including new technology and codified knowledge in patents, by means of the specialized press and scientific journals as well as the good networking skills. Knowledge workers have to be well connected in order to both receive relevant information as well to spread this information within the organization.

Of course, making information merely flow through the organization is not yet enough. Ideas, new technology and knowledge also have to be absorbed by the organization and find their way into processes at the end of which lie innovation and the introduction of competitive products. Innovation and knowledge management therefore includes the skills to bring an innovation from the 'drawing board' into the organization. These implementation skills relate closely to the strategic, organizational and interpersonal skills that we will discuss in the next section.

\subsection{The emergence of high performance work places and the mobilization of human resources}

\section{Emergence of high performance work places}

The centrality of knowledge work and increasing levels of market uncertainty requires organizational changes within firms. It is widely believed that traditional bureaucratic management stifles innovation and is ill-equipped for optimally using the potential of knowledge workers. Organizations which heavily rely on knowledge workers to increase productivity and competitiveness, and which adapt their organizational structure accordingly, have been labelled "high performance organizations" (OECD, 1999). What distinguishes them from other organizations is that the high performance work places they design involve a broad range of skills and task variety, the extensive use of team work, reduced hierarchical levels, and the delegation of responsibility to individuals and teams (Betcherman, 1997). As it becomes increasingly difficult for managers to keep pace with 
technological developments, an argument in favour of giving knowledge workers more weight within the organization is to better align strategic decisions with the latest innovations. Moreover, flattening hierarchies potentially increases the speed of decisions in the face of market uncertainty.

Organizations which adopt high performance work practices have been found to have higher productivity and better financial performance (e.g. Appelbaum, Bailey, Berg and Kalleberg, 2000; Bartel 2004; Black and Lynch 2004). High performance organizations engage workers in the broader production process and provide them with comprehensive understandings of organizational goals and priorities (Bills, 2004). The organization supplies knowledge workers with the means to attain agreed goals and gives them autonomy with regard to the path to get there.

This trend towards decentralized decision making has partly been facilitated by technological change. There is a strong relationship between the introduction of high performance workplaces and investment in ICT (Arnal, Ok and Torres, 2001). Autonomous teams are now able to complete whole processes that had earlier been fragmented due to the lack of centralized databases. Not only has IT changed production processes, it is increasingly a feature of new products, as well. Organizational changes can contribute to the development of innovative products by forming teams with complementary expertise (e.g. automotive engineers and electronic engineers). Alternatively, workers may have to be experts in more than one field. As the work places which emerge from this kind of organizational change demand a highly complex set of skills, it is often labelled skill biased organizational change (European Commission, 2008).

Measuring the incidence of high performance work places is difficult. Most surveys rely on questions which ask whether firms have adopted or plan to adopt work practices that are an integral part of high performance work places, such as team work, job rotation and the delegation of responsibility. Further, incidence, and also meaning of these work practices differ between countries. Critics of the literature on high performance work places are therefore sceptical that organizational changes towards more flexible firms present real revolutionary changes (Pollert, 1988; Ramsay, 1996; Bernstein, 1997). Instead, these authors suggest that new work practices could be management "fads", old wine in new bottles.

Although it is difficult to say to what extent high performance work places are ousting traditional work places, there is some evidence that there is an upward trend in their diffusion. The proportion of firms adopting new work practices is on the rise (Arnal et al., 2001) and with it the demand for the skills they require. 


\section{Mobilization of human resources}

The emergence of high performance work places sets high expectations on the mobilization of human resources. If knowledge workers are required to optimally mobilize their own and others' human capital, they need to have at least the following skills: 1. Interpersonal skills (the ability to work in a team and communicate and cooperate effectively with diverse colleagues and clients); 2. Self-(management) skills (the ability to work within budget and time constraints, leadership) and 3. strategic-organizational skills (the ability to act strategically towards the achievement of organizational goals).

The importance of interpersonal skills is not unique to the $21^{\text {st }}$ century (Dede, 2010). It is obvious, however, that the skills demanded of workers in settings characterized by autonomous teams with shared decision making differ from those of workers in traditional hierarchical work settings. Traditionally, interpersonal skills are the domain of managers, who have to be effective in getting others to achieve the organizational goals without necessarily being experts themselves. In high performance work places, however, teams and workers are given responsibilities ranging from production, training and product innovation to customer relations and marketing. Organizational goals are attained by teams of workers with complementary professional expertise (Karoly, 2004). This involves a high degree of information-sharing and communication and fundamentally increases the worth of collaborative capacity for non-management level workers. Having to interact in socially heterogeneous groups makes it necessary to relate well to others, to cooperate and to manage and resolve conflict (Rychen and Salganik, 2003). Working in teams and making shared decisions, demands workers to be able to communicate effectively, evaluate their work and the work of others, influence team mates and to seek advice, information and support when appropriate. The importance of these skills for professionals in Europe has been documented by Felstead, Gallie, Green and Zhou (2007), Allen (2011) and Miles and Martinez-Fernandez (2011).

Reduced hierarchical levels open up opportunities for professional development. The work of knowledge workers is outcome oriented and the employer's capacity to monitor the working process is low. It is therefore in the interest of the employer to employ individuals with strategicorganizational skills, that is the ability to direct their actions independently towards attaining the organizational goal. High degrees of autonomy must not result in knowledge workers leading a selfcentred, isolated work life within organizations. Knowledge workers must know their position in the organization and must be able to link their work to the tasks of others. In high performance workplaces, strategic thinking, being able to set one's task in the greater organizational context become key skills for professional and organizational success. 
The high level of autonomy requires knowledge workers to have good self-management skills, like the ability of work within time and budget constraints. Traditionally graduates have also been called upon to exert leadership skills. But instead of the 'traditional' leader, the high performance work places require knowledge workers to have non-traditional management skills, such as the ability to mobilize the capacities of others in the team.

By nature, it is difficult for others to judge whether the professional expertise of knowledge workers is still up to date. Traditional bureaucratic institutions within organizations are ill-equipped for governing training and learning of autonomously working experts. Consequently, knowledge workers have to administer their human resources themselves. They have to be aware of latest innovations and make sure that they remain at the forefront of their field of expertise. Knowledge workers therefore have to be able to identify skill shortages and to eliminate them by training and selfdirected learning. This is closely related to the before-mentioned employability skills.

\subsection{Globalisation and international orientation}

\section{Globalization}

Globalization - the strengthening and acceleration of world-wide interconnectedness - has certainly been facilitated by the development of ICT. Never before has an economy had the capacity to work as a unit in real time on a planetary scale (Castells, 2000). Globalization affects trade levels, production processes, information flows and the competitive environment in which organizations operate. Globalization is therefore also related to the emergence of the knowledge society, the implementation of high performance work places as well as the flexibilization of the relationship between employers and employees. At this point, however, we would like to highlight the extent to which globalization increases the demand for an international orientation.

Globalization is characterized by fast flows of ideas, financial capital, goods, services and people across national borders. As a result, interaction with people from other cultures and with other linguistic backgrounds becomes more common and is now part of the working life of a substantial proportion of the higher educated workforce. Around one third of European graduates work in organizations whose scope of operation is international (Pavlin and Svetlik, 2011). The same proportion indicates that the ability to speak and write in a foreign language is highly required in their job.

Growing global interdependence is certainly one major driving force behind this development. A substantial proportion of workers' regular customer contact, brainstorming and consultation with 
colleagues, and decision-making nowadays takes place across national borders or involves groups of people with diverse national backgrounds. At the same time, the flattening of hierarchical levels also impacts the number of individuals who work within culturally heterogeneous groups. This is because decentralizing decision-making not only grants groups of professionals more autonomy. It also shifts large amounts of communication from higher levels of the hierarchy to the working level. Whereas traditionally the managerial level tended to be the recipient and the distributor of information, today the exchange of information increasingly takes place directly between professionals.

\section{International orientation}

International orientation requires knowledge workers to have: 1. A good proficiency of foreign languages and 2. Intercultural skills (the ability to work with people from different cultural backgrounds and the ability to adapt to new cultural contexts).

Almost anybody will have heard some anecdote where intercultural communication has gone completely wrong and where business intention dramatically failed as a result. Working and interacting with individuals of different cultural and linguistic backgrounds, not just in a casual setting but in goal-oriented work settings, presupposes an elevated degree of foreign language skills and cultural sophistication. Naturally, a precondition of any goal-oriented interaction between individuals of diverse national backgrounds is to have a common language foundation. Individuals working in international contexts have to be able to understand spoken messages, to initiate, sustain and conclude conversations and to read, understand and produce texts appropriate to the firm's needs (European Commission, 2007).

Yet even if this pre-condition is fulfilled, management activities, collaborations or negotiation efforts in intercultural settings can suffer significant setbacks when patterns of thought or behaviour of others are misinterpreted. Selling products abroad can fail simply by not adjusting marketing strategies and sometimes the product itself to the particularities of the foreign market (Verluyten, 2001). Today's graduates increasingly have to be able to take a step backwards from self-reference and familiar frameworks and adapt to new cultural contexts. These intercultural skills include knowing - or at least being aware of - particular cultures of e.g. negotiation, politeness, decision making, team work of executives, colleagues, partners or clients. 


\subsection{The change of the economic structure and entrepreneurship}

The change of the economic structure

Over the last decades deregulation, technological change and globalization have fundamentally changed the competitive environment in which organizations operate and have resulted in an unprecedented growth of the service sector. At the same time, the relative importance of small and medium sized firms has increased substantially. To give an often cited example, between 1970 and 1996, the share of employment of the 500 largest US firms dropped from 20 per cent to 8.5 per cent (Carlsson, 1992 and 1999). Partly, this can be accounted for by firms' reaction to international competition in the form of organizational changes such as decentralization and vertical disintegration (Loveman and Sengenberger, 1991). In addition, there is evidence that the economic environment after the early 1970's has been most favourable for small and medium sized enterprises. Amongst other factors, technological changes may have reduced optimal firm size and the minimum scale of entry and deregulation of markets may have created opportunities for small and medium sized businesses (Brock and Evans, 1989). Increasing market risk due to international competition as well as the change in consumer preferences towards customized products may have favoured smaller firms as they are often said to be more flexible (Piore and Sabel, 1984; Meredith, 1987; Carlsson, 1989) and innovative (Acs, 1992; Audtretsch and Thurik, 2000; Carree and Thurik, 2003). The superiority of small and medium enterprises with regard to flexibility, innovation and job creation has, however, often been challenged (Williams, Cutler, Williams and Haslam, 1987; Semlinger, 1992; Weimer, 1992; Parker, 2001). Moreover, Brock and Evans (1989) point to the possibility that the growing share of employment in small and medium enterprises may be a temporary phenomenon rather than a long-term trend. Whatever the reason for the change in the economic structure, the observed growth of importance of small and medium enterprises for employment in combination with the flattening of hierarchies within firms increases demand for graduates who are comfortable with assuming responsibility and with contributing to the success of the organization through entrepreneurship. Audretsch and Thurik (2000) even point to the centrality of entrepreneurship at the country level. For high-wage countries whose key comparative advantage lies in the generation of knowledge and innovation, entrepreneurship may be one of the main ingredients of global competitiveness. At the firm or within-firm level, entrepreneurship can be understood as "the discovery, evaluation and exploitation of future goods and services" (Eckhardt and Shane, 2003: $336)^{2}$. At the institutional level, entrepreneurship involves "changing the structure within which economic and other activities take place" (Crouch, 2005: 101). The importance of entrepreneurship is

2. According to Eckhardt and Shane, their definition of entrepreneurship follows Venkatamaran (1997). 
therefore not confined to knowledge workers working in the private sector but is also relevant for the work of institutional entrepreneurs in the public sector.

\section{Entrepreneurship}

The following skills are important components of entrepreneurship: 1. The ability to identify commercial risks and opportunities; 2. A good sense of cost awareness and 3. The ability to turn an idea into a successful product.

Whenever knowledge workers assume a central role within an organization, they have to be increasingly alert to changes in markets and innovations. This not only includes evaluating how developments affect their own work, but also to draw the consequences for the organization as a whole. The higher the degree of autonomy knowledge workers enjoy within the organization, the more important their ability to independently contribute to the organization's economic and commercial success. This is true for owners of a firm as well as for employees both in the private and the public sector. Having entrepreneurial skills/commercial awareness has two important advantages for graduates. On the one hand, as with the other skill demands, it helps them fulfil the requirements of (potential) employers and to improve their position on the labour market. On the other hand, it provides them with the basis for starting their own businesses and becoming employers themselves.

As shown above, the centrality of knowledge work has led to an increased demand for interpersonal, strategic thinking and innovation skills. To some extent, entrepreneurship and commercial awareness could have been discussed as a part of these skill demands. Yet, it is worthwhile devoting a separate section to them for two reasons. Firstly, it underlines their importance for the survival of organizations and the competitiveness of entire economies. Secondly, it enables us to highlight the facilitating and commercial as opposed to the creative side of innovation.

It is important to note that the importance of entrepreneurial skills is not confined to the private sector. Globalization does not only result in international competition among firms but also between countries and regions. Today, one of governments' main challenge is to create institutions which best unfold creative capacity and innovation and which facilitate economic growth. Against this background, institutional entrepreneurs are actors who purposefully leave existing paths and recombine existing governance mechanisms to create new, innovative institutional environments (Crouch, 2005).

At the firm level, the trends we identify contribute to the blurring of the boundaries between entrepreneurs managing their own firm and knowledge workers fulfilling central tasks within an organization. Boundaries become blurred because an increasing proportion of the workforce is 
required to possess entrepreneurial skills and commercial awareness. This refers to the ability to perceive changes in the market and to identify competitors as well as commercial risks and opportunities. It also pertains to the awareness of the costs associated with one's activities and costs of decisions. Potentially most importantly, it refers to the ability to recognize the commercial value of an idea and to search for and pursue opportunities to turn them into successful products.

The existence and the characteristics of such opportunities are of major importance for the process of entrepreneurship (Eckhardt and Shane, 2003). However, one central question with regard to the relationship of higher education and entrepreneurship is whether the specificity of education influences graduates' ability to pursue opportunities. Lazear (2005) argues that entrepreneurs need to possess a relatively broad and balanced set of skills which enables them to pursue opportunities they identify in the face of uncertainty and obstacles. For example, next to the conception of the basic product, entrepreneurs are usually involved in hiring the initial team and obtaining some early financing. Entrepreneurs must certainly possess professional expertise, but it is the combination of professional expertise with the ability to perceive market opportunities which really distinguishes them from other experts. As Lazear (2005: 661) puts it: "A technical engineer may be superb at creating a new device, but that device may not have any business value. The innovator who succeeds is the one who can come up with something that is not only technically sound but business relevant as well." Lazear is pointing to the paradox that for business, it might sometimes be advantageous to be able to take a step backwards from technical details in order to concentrate on business value and market relevance. Commercially successful products are not necessarily the most innovative ones. An entrepreneur needs to possess the ability to handle the complex relationship between a product's price, quality and degree of innovation. Studies examining the determinants of entrepreneurship regularly find that business owners and self-employed ${ }^{3}$ have a more balanced, generalist skill set than employees. Lazear $(2004,2005)$, supported by Wagner $(2003,2006)$, argues that this is the result of a trade-off between professional expertise and entrepreneurship and that individuals intending to become entrepreneurs purposefully acquire more general human capital. Other studies, however, suggest that the generalist profile of entrepreneurs is the outcome of differences in innate ability (Silva, 2007) or a greater taste for variety (Astebro and Thompson, 2011).

Entrepreneurs are conceptually distinct from self-employed individuals offering some kind of wellestablished services, such as tax counselling. These individuals do not rely on the broad set of skills crucial to entrepreneurs as they do not need to possess the versatility necessary to perceive market

3. This definition of entrepreneurs which ignores employees involved in entrepreneurial activities can be ascribed to a lack of better measures in the data used in these studies. 
opportunities for new products and identify employees suitable for achieving the (new) firm's objectives (Lazear, 2005).

\section{Some Key Issues Concerning the Role of Higher Education}

Understanding the different trends on the labour market and its effects on the skills that graduates need to have in order to stay employable is only the first piece of the puzzle. In order to make use of this knowledge, we need to understand the features of higher education that enable students to develop these skills. Although prior research (e.g. Allen and Van der Velden, 2011) has shown that things such as international experience, work experience and practical experience during higher education can be highly effective in promoting graduate employability, we are still very remote from having a full understanding of the mechanisms that drive skill acquisition in education and how this process of skill formation can be improved (Cunha and Heckman, 2007). We will therefore refrain from providing a 'recipe' as to how higher education institutions should adapt their courses and what actions they should take. Instead we will distil some key insights into how higher education can position itself in skill formation today.

\section{Produce an ideal mix of graduates rather than an ideal graduate}

The above exposé of skill demands seems to suggest that higher education should produce graduates who are not only experts in their own field, but at the same time also flexible, innovative, strategic, communicative, international oriented and entrepreneurial. In practice such "Jacks-of-all-trades" hardly exist and most people will have their strong and weak points. Even more important, there is no evidence that employers actually want all these skills to be united in one person. The above trends relate more to the mix of skills that is required on the labour market on an aggregate level, rather than an individual level. This means that choices can and should be made and that students can specialize in one or more of these domains. This specialization will in fact increase overall productivity. The question will remain however, what the minimum level of skills is in each domain that is required from each graduate to be employable and to be able to work with other graduates who have complementary skills. These minimum skills will primarily relate to the broad academic skills that are part of the professional expertise, the ICT related skills and the skills related to an effective mobilization of human resources (strategic-organizational and interpersonal skills). 


\section{Make a good choice of which skills should be developed in higher education and which}

not

Even if we agree that some specialization can take place and not every skill needs to be acquired by every student, there will still be more demand for skills than can possibly be developed in education. The following trade-offs and tensions are commonly grappled with in all societies where there are growing numbers of students entering higher education:

1. Is higher education the most efficient environment to develop this skill, or is it more efficiently acquired in private-life or during firm-based training?

For many academic skills it is evident that higher education is a suitable place to develop them. However this probably does not apply to all the skills we have mentioned. E.g. it is questionable whether entrepreneurial skills are best developed in the typical environment of a university or that it is more efficiently acquired elsewhere. And the same may apply for some of the other skills.

\section{What is the best age to develop this skill?}

The typical age range in which students are in higher education is between 18-25. Some of the skills that we have discussed earlier may be better developed at an earlier or a later stage in the educational career. The acquisition of foreign language skills should typically occur before entering higher education, while for other skills students need some 'life-experience' or 'work-experience' to be able to develop them (e.g. strategic-organizational or management skills).

\section{What is the trade-off between developing one skill instead of another skill?}

Sometimes skills can be developed together by choosing the appropriate teaching method (see below) and then there is no trade-off. However in many cases such trade-offs do exist and spending more time on one skill will be at the expense of developing another skill. Higher education institutions need to identify where these trade-offs exist and need to balance the long-term benefits of developing each type of skill.

4. Is the development of this skill a prerequisite for the development of other relevant skills?

Sometimes a certain skill is not directly needed on the labour market or in society, but it is considered an important skill to develop other skills that are directly needed. One can think of basic introductions in the philosophy of science that are probably needed in every discipline in order to develop professional and academic skills. Higher education institutions need to consider these foundation skills as well when designing their curriculum. 


\section{Specialists or generalists? Do not underestimate the importance of specific knowledge}

In today's fast-changing world, many people think that specific knowledge is not so important anymore. The idea seems to be that most of the specific knowledge can be found on the internet and that teaching specific knowledge is a waste of time as the technological developments will render this type of knowledge soon obsolete. Instead of specialists, they argue that higher education should produce generalists. However this is a total misconception of how people learn and what the role is of specific knowledge in this process. The cognitive science literature has accumulated convincing evidence that solving expert tasks requires content-specific skills and knowledge, and that general skills alone have no practical utility. In the words of the German psychologist Weinert: "Generally, key competencies cannot adequately compensate for a lack of content-specific competencies." (Weinert, 2001: 53). Some researchers even doubt whether truly generic competences exist, and argue that even generic competences (like analytical thinking or communication skills) are contextbound (Perkins and Salomon, 1989).

The relevance of specific knowledge is also found in labour market studies such as HEGESCO (Allen, Pavlin and Van der Velden, 2011) and REFLEX (Allen and Van der Velden, 2011). These studies have shown that professional expertise is the most important driver of individuals' labour market success, even if a graduate is working outside his or her own domain. It suggests that professional expertise can be understood as a vehicle for developing general skills. It is therefore important that higher education keeps paying attention to the development of professional expertise, by designing programmes which are coherent and lead to a specific body of knowledge.

\section{Striking a balance between skills that are needed for the short-term and long-term}

One goal of higher education is to support students in acquiring the skills that help them make a good start on the labour market. This means that graduates should have acquired some skills that can be instantly deployed on the labour market. On the other hand, higher education also needs to equip the students with the skills that make them employable in the long run and ensure a good career. Faced with these two goals - providing an entry ticket to the labour market and ensuring long-term employability - higher education institutions need to strike a balance between broad professional skills and more narrow professional skills. To avoid misunderstanding, this does not refer to the discussion on generalists versus specialists touched upon above. Even if we agree that higher education should produce professional experts, there is still a matter of the extent of specialization that should be strived for. The challenge is to strike a fine balance between the two goals and the difficulty is to pin down exactly when the line is crossed. There is an inherent tendency 
of higher education institutions to offer ever more specialized study programmes. This is related to the fact that these institutions compete on a student-market and need to be able to distinguish from each other. But for the graduates themselves this specialization decreases their long-term employability. And even for employers the large number of programmes offered prevents transparency and decreases the recognition and credibility of these degrees on the labour market. Overall, higher education institutions have to take into account that offering study programmes whose focus is too broad or too narrow has major repercussions for the short- or long-term employability of the graduates and the transparency of educational credentials on the labour market.

\section{Curriculum is not the only driver of skills acquisition}

The naïve but still popular conception of education is that the curriculum defines what students learn. However, the learning formats used and the way in which higher education assesses the students drives the learning process as well. Student-centred methods like problem-based learning or group work play an important role in developing many of the so-called $21^{\text {st }}$ century skills (Allen and Van der Velden, 2012). Self-directedness is promoted whenever tasks involve working independently, making choices and taking decisions autonomously and directing one's own learning process. Interactive skills are learned when working in groups or using negotiation and discussion techniques in tutorials, and reflectiveness is practiced when thinking about the relationship between the method (e.g. team work) and the results (the group's product) (OECD, 2010).

The same applies for the assessment of students. Students learn little from multiple choice exams where success is more dependent on a student's short-term memory capacity than his or her analytical skills. Paying attention to the proper forms of assessment is therefore crucial for the development of the skills that have been outlined before as relevant for graduates (Wiliam, 2010).

The ICT revolution plays a specific role in this. It does not only generate new ICT-related skill demands, but it also changes education itself. ICT can be turned into a powerful tool to develop relevant skills, by opening up new possibilities in terms of content (e.g. open content), learning environment (e.g. virtual reality systems), teaching resources (e.g. distance teaching), diagnosis (e.g. intelligent tutoring systems) and assessment (e.g. authentic assessment). Many of the challenges higher education is facing can only be solved by successfully implementing the plethora of possibilities that ICT offers.

\section{The need for higher education to become more international oriented}

About $40 \%$ of European graduates work in a company operating on an international scale or an international environment where the ability to speak and write a foreign language is highly required 
(Allen and Van der Velden 2011). Higher education should prepare graduates accordingly. The world of work has become internationalized to a great extent over the last 25 years and it is likely to continue moving in this direction. If we look at research and science, for example, 25 years ago work life was almost entirely nationally focused, as was the presentation of research output in national workshops and conferences and its publication in national journals. Today, the reverse is true. National journals not publishing in English are marginalized and workshops and conferences almost exclusively take place in an international setting. Admittedly, some sectors of the economy are more exposed to internationalization than others, and research might not be a representative example. Yet, it can be regarded a herald for the developments in other areas of the economy. Technology, banking, and manufacturing, to name but a few, have experienced similar processes of internationalization and others are likely to follow.

Higher education is internationalizing, but not at the speed necessary to keep up with what is happening in the world of work. Graduates who have insufficient knowledge of foreign languages to communicate with others will likely be limited in their professional development and labour market opportunities. Organizations might be able to absorb some of the negative effect of a shortage of people with sufficient international orientation by adjusting their organizational structure. Nevertheless, also for them this shortage will likely present constraints to their potential for development and expansion. Higher education institutions should continue to encourage students to do parts of their studies or compulsory internships abroad. They should also think about offering more courses - or entire study programmes - in foreign languages.

\section{Summary and Concluding Remarks}

In this paper, we brought forward the idea that societal, economic and organizational trends are changing the work environment of graduates and that this requires purposive actions on the side of higher education institutions. We identified 6 trends which are at the core of the changing role of graduates in economic life. These trends are the knowledge society, increasing uncertainty, the ICT revolution, high performance workplaces, globalization, and the change of the economic structure. By changing the nature and range of tasks graduates are expected to fulfil in today's economy, these trends generate new and intensify traditional skill demands, which we summarized as professional expertise, flexibility, innovation and knowledge management, mobilization of human resources, international orientation, and entrepreneurship.

These skills relate to different aspects as indicated in the following table. 
Table: skills and related aspects

\begin{tabular}{|c|c|}
\hline \multirow[t]{3}{*}{ Professional expertise } & Specific body of knowledge \\
\hline & Ability to apply expert thinking \\
\hline & $\begin{array}{l}\text { General academic skills (e.g. analytical thinking, } \\
\text { reflectiveness) }\end{array}$ \\
\hline \multirow[t]{3}{*}{ Flexibility } & Ability to deal with changes and uncertainty \\
\hline & Ability to learn new things \\
\hline & $\begin{array}{l}\text { Employability skills (e.g. the willingness to invest in } \\
\text { further education and training, and the ability to plan } \\
\text { and take responsibility for one's own career) }\end{array}$ \\
\hline \multirow[t]{3}{*}{$\begin{array}{l}\text { Innovation and knowledge } \\
\text { management }\end{array}$} & Innovative/creative skills (creativity, curiosity) \\
\hline & Networking, information and strategic ICT skills \\
\hline & Implementation skills \\
\hline \multirow[t]{3}{*}{$\begin{array}{l}\text { Mobilization of human } \\
\text { resources }\end{array}$} & $\begin{array}{l}\text { Interpersonal skills (communication skills, teamwork } \\
\text { skills) }\end{array}$ \\
\hline & $\begin{array}{l}\text { (Self-)management skills (working within budget and } \\
\text { time restrictions, leadership) }\end{array}$ \\
\hline & Strategic-organizational skills \\
\hline \multirow[t]{2}{*}{ International orientation } & Foreign language skills \\
\hline & Intercultural skills \\
\hline \multirow[t]{3}{*}{ Entrepreneurship } & Ability to identify commercial risks and opportunities \\
\hline & Cost awareness \\
\hline & Ability to turn an idea into a successful product \\
\hline
\end{tabular}

A key concern which we tried to convey is the changing demand for and character of the professional expertise developed in higher education. In the second part of this paper, we presented possible implications of these developments for higher education. We drew out the key issues concerning the role of higher education institutions in skill formation. These key issues can be summarised as follows:

- The need to produce an ideal mix of graduates rather than an ideal graduate; 
- The need to spent the scarce resources in higher education as effective and efficient as possible by making a good choice of which skills should be developed in higher education and which not;

- The understanding that specific knowledge is crucial for developing expertise;

- The need to strike a balance between skills that are needed for the short-term and long-term employability;

- The understanding that curriculum is not the only driver of skills acquisition, but that teaching methods and assessment are just as important ;

- The need for higher education to become more international oriented.

While we were able to give a general overview, the key issues and trade-offs we distilled will, however, differ between countries and within countries between types of higher education institutions. The positioning of higher education institutions in skill formation will depend on the degree to which the labour market they are supplying is exposed to the six trends we identified, the institutional environment they are operating in, and the kind of student flows they are servicing at the international, national and regional level. ${ }^{4}$ Consequently, there will be no standard solution to the trade-offs highlighted above but policy makers and higher education institutions need to find their own optimal strategy. The most important concern is that national policy makers and higher education institutions are aware of what is expected of higher education graduates in the $21^{\text {st }}$ century and define their strategies accordingly.

\section{References}

Acemoglu, D. (1998). Why Do New Technologies Complement Skills? Directed Technical Change and Wage Inequality. The Quarterly Journal of Economics, 113, 1055-1089.

Acs, Z.J. (1992). Small Business Economics: A Global Perspective. Challenge, 35, 6, 38-45.

Allen, J. (2011). Mobilization of Human Resources. In: J. Allen and R. Van der Velden (eds.), The Flexible Professional in the Knowledge Society: New Challenges for Higher Education. Dordrecht, Heidelberg, London, New York: Springer, 139-176.

Allen, J., Pavlin, S. and Van der Velden, R. (eds.) (2011). Competencies and Early Labour Market Careers of Higher Education Graduates in Europe. University of Ljubljana: Faculty of Social Sciences.

4. Institutional differences between countries have been extensively analyzed with regard to 'elite' versus mass' education (Trow, 2000), the level and type of educational differentiation (Shavit, Arum, and Gamoran, 2007), the degree of curricula standardization (Allmendinger, 1989), and individuals' transition from initial education to the labour market (Müller and Gangl, 2003; Van der Velden and Wolbers, 2003). 
Allen, J., Coenen, J. and Humburg, M. (2011). The Transition and Early Career. In: J. Allen, S. Pavlin and R. Van der Velden (eds.), Competencies and Early Labour Market Careers of Higher Education Graduates in Europe. University of Ljubljana: Faculty of Social Sciences, 29-54.

Allen, J. and Van der Velden, R. (2011). The Flexible Professional in the Knowledge Society: New Challenges for Higher Education. Dordrecht, Heidelberg, London, New York: Springer.

Allen, J. and Van der Velden, R. (2012). Skills for the 21st Century: Implications for Education. ROARM-2012/11, Maastricht: Research Centre for Education and the Labour Market. Accepted for publication in: Higher Education: Recent Trends, Emerging Issues and Future Outlook, Nova Publishers.

Allmendinger, J. (1989). Educational Systems and Labour Market Outcomes, European Sociological Review, 5, 231-250.

Appelbaum, E., Bailey, T., Berg, P. and Kalleberg, A.L. (2000). Manufacturing Advantage: Why HighPerformance Work Systems Pay Off. Ithaca, N.Y.: ILR Press

Arnal, E., Ok, W. and Torres, R. (2001). Knowledge, Work Organisation and Economic Growth, OECD Labour Market and Social Policy Occasional Papers, 50, Paris: OECD Publishing.

Astebro, T. and Thompson, P. (2011). Entrepreneurs, Jacks of all trades or Hobos? Research Policy, 40, 637-649.

Audretsch, D.B. and Thurik, A.R. (2000). Capitalism and democracy in the 21st Century: from the managed to the entrepreneurial economy. Journal of Evolutionary Economics, 10, 17-34.

Bartel, A. P. (2004). Human Resource Management and Organizational Performance: Evidence from Retail Banking. Industrial and Labor Relations Review, 57, 1, 181-202.

Bell, D. (1999). The Coming of Post-Industrial Society: A Venture in Social Forecasting. New York: Basic Books.

Bernstein, P. (1997). American Work Values: Their Origin and Development. Albany: State University of New York Press.

Betcherman, G. (1997). Changing Workplace Strategies: Achieving Better Outcomes for Enterprises, Workers and Society. Ottawa: Government of Canada and OECD.

Bills, D.B. (2004). The Sociology of Education and Work. Malden, Oxford and Victoria: Blackwell.

Black, S. E. and Lynch, L. M. (2004). What's driving the New Economy: the benefits of workplace innovation, Economic Journal, 117, 97-116.

Brenner, R. (2006). The Economics of Global Turbulence. The Advanced Capitalist Economies from Long Boom to Long Downturn, 1945-2005. London, New York: Verso.

Brock, W.A. and Evans, D. S. (1989). Small business economics, Small Business Economics, 1, 7-20.

Carlsson, B. (1989). The Evolution of Manufacturing Technology and its Impact on Industrial Structure: An International Study, Small Business Economics, 1, 21-37. 
Carlsson, B. (1992). The Rise of Small Business: Causes and Consequences. In W.J. Adams (ed.), Singular Europe, Economy and Policy of the European Community after 1992. Ann Arbor, MI: University of Michigan Press, 145-169.

Carlsson, B. (1999). Small Business, Entrepreneurship, and Industrial Dynamics. In Z. Acs (ed.), Are Small Firms Important? Boston/Dordrecht: Kluwer Academic Publishers, 99-110.

Caroli, E. and Van Reenen, J. (2001). Skill-Biased Organizational Change: Evidence From A Panel Of British and French Establishments, The Quarterly Journal of Economics, 116, 4, 1449-1492.

Carree, M.A. and Thurik, A.R. (2003). The Impact of Entrepreneurship on Economic Growth. In Z.J. Acs and D.B. Audretsch (eds.), Handbook of Entrepreneurship Research, Kluwer Academic Publishers, 437-471.

Castells, M. (1996). Enterprises and Jobs: Jobs in the Network Enterprise. Discussion paper for the ILO Enterprise Forum 96, www.ilo.org.

Castells, M. (2000). The Rise of the Network Society ( $2^{\text {nd }}$ edition). Cambridge, MA, Oxford: Blackwell.

Crafts, N. and Toniolo, G., (1996). Postwar Growth: An overview. In: N. Crafts and G. Toniolo (eds.), Economic Growth in Europe since 1945, Cambridge University Press: Cambridge, 1-37.

Crouch, C. (2005). Capitalist Diversity and Change: Recombinant Governance and Institutional Entrepreneurs. Oxford: Oxford University Press.

Cunha, F. and Heckman, J. (2007), The Technology of Skill Formation, American Economic Review, 97, 2, 31-47.

Dede, C. (2010). Comparing Frameworks for 21st Century Skills. In J. Bellanca and R. Brandt (eds.), 21st Century Skills. Bloomington, IN: Solution Tree Press, 51-76.

DiPrete, T. A., Goux, D., Maurin, E. and Quesnel-Vallee, A. (2006). Work and Pay in Flexible and Regulated Labor Markets: A Generalized Perspective on Institutional Evolution and Inequality Trends in Europe and the US, Research in Social Stratification and Mobility, 24, 311-32.

Eckhardt, J.T. and Shane, S.A. (2003). Opportunities and Entrepreneurship, Journal of Management, 29, 3, 333-349.

Ericsson, K.A. and Crutcher, R.J. (1990). The Nature of Exceptional Performance. In: P.B. Baltes, D.L. Featherman and R.M. Lerner (eds.), Life-Span Development and Behavior. Hillsdale, NJ: Lawrence Erlbaum.

European Commission (2007). Key Competences for Lifelong Learning - A European Framework. Luxembourg: Office for Official Publications of the European Communities.

European Commission (2008). New Skills for New Jobs: Anticipating and Matching Labor Market and Skills Needs. Commission Staff Working Document. Brussels: European Commission.

Felstead, A., Gallie, D., Green, F. and Zhou, Y. (2007). Skills at Work, 1986 to 2006, Universities of Oxford and Cardiff, ESRC Centre on Skills, Knowledge and Organisational Performance. 
Froud, J., Shukdev, J., Leaver, A. and Williams, K. (2006). Financialization and strategy: narratives and numbers, London: Routledge.

Greenan, N. (2003). Organizational Change, Technology, Employment and Skills: An Empirical Study of French Manufacturing, Cambridge Journal of Economics, 27, 287-316.

Hage, J., and Powers, C.H. (1992). Post-Industrial Lives: Roles and Relationships in the $21^{\text {st }}$ Century. Newbury Park: Sage.

Hayes, J. (1981). The Complete Problem Solver. Philadelphia: The Franklin Institute Press.

Hujer, R., Caliendo, M. and Radic, D. (2002). Skill Biased Technological and Organizational Change: Estimating a Mixed Simultaneous Equation Model Using the IAB Establishment Panel. IZA Discussion Paper No 566, Bonn: IZA.

Karoly, L. A. (2004). The 21st Century at Work: Forces Shaping the Future Workforce and Workplace in the United States. Santa Monica, CA: RAND Corporation.

Lazear, E. P. (2004). Balanced skills and entrepreneurship, American Economic Review, $94,2,208-211$.

Lazear, E.P. (2005). Entrepreneurship, Journal of Labor Economics, 23, 4, 649-680.

Levy, F. (2010). How Technology Changes Demands for Human Skills, OECD Education Working Papers 45. Paris: OECD Publishing.

Loveman, G. and Sengenberger, W. (1991). The re-emergence of small-scale production; an international comparison, Small Business Economics, 3, 1-37.

Meredith, J. (1987). The Strategic Advantages of New Manufacturing Technologies for Small Firms, Strategic Management Journal, 8, 249-258.

Miles, I. and Martinez-Fernandez, C. (2011). Implications for Skills, Employment and Management. In: C. Martinez-Fernandez, I. Miles and T. Weyman (eds.), The Knowledge Economy at Work: Skills and Innovation in Knowledge Intensive Service Activities, Cheltenham: Edward Elgar, 239-265.

Müller, W., and Gangl, M. (2003). The transition from school to work. A European perspective. In W. Müller and M. Gangl (Eds.), Transitions from education to work in Europe. The integration of youth into EU labour markets. Oxford: Oxford University Press, 1-19.

Muffels, R.J.A. (2008). Flexibility and Employment Security in Europe: Setting the Scene. In R.J.A Muffels (ed.), Flexibility and Employment Security in Europe: Labour Markets in Transition. Cheltenham, Northampton: Edward Elgar, 3-30.

OECD (1999). Economic Outlook. Paris: OECD Publishing.

OECD/Eurostat (2005). Oslo Manual: Guidelines for Collecting and Interpreting Innovation Data (3rd edition). The Measurement of Scientific and Technological Activities. Paris: OECD Publishing.

OECD (2010). The Nature of Learning: Using Research to Inspire Practice, Paris: OECD Publishing. 
OECD (2012). Literacy, Numeracy and Problem Solving in Technology-Rich Environments: Framework for the OECD Survey of Adult Skills. Paris: OECD Publishing.

Parker, R. (2001).The myth of the entrepreneurial economy: Employment and innovation in small firms. Work, Employment and Society, 15,2, 239-253.

Pavlin, S. and Svetlik, I. (2011). The World of Work and the Demand for Competences. In: J. Allen, S. Pavlin and R. Van der Velden (eds.), Competencies and Early Labour Market Careers of Higher education Graduates in Europe. University of Ljubljana: Faculty of Social Sciences, 73-106.

Perkins, D.N. and G. Salomon (1989). Are Cognitive Skills Context Bound?, Educational Researcher, 18, 16-25.

Piore, M.J. and Sabel, C.F. (1984). The Second Industrial Divide: Possibilities for Prosperity. New York: Basic Books.

Pollert, A. (1988). The "Flexible Firm": Fixation or Fact?, Work, Employment and Society, 2, 281-316.

Ramsay, H. (1996). Managing Sceptically: A Critique of Organisational Fashion. In: S.R. Clegg and G. Palmer (eds.), The Politics of Management Knowledge. New York: Russell Sage Foundation, 155-172.

Reich, R. B. (1992). The Work of Nations: Preparing Ourselves for 2Ist-CenturyCapitalism. New York: Knopf.

Rychen, D.S., and Salganik, L.H. (eds.) (2003). Key Competencies for a Successful Life and a WellFunctioning Society. Göttingen: Hogrefe and Huber.

Schmid, G. (1998). Transitional Labor Markets: A new European Employment Strategy. WZB Discussion Paper FS I 98-206. Berlin: WZB.

Semlinger, K. (1992). Small Firms in Big Subcontracting. In: N. Altmann, C. Koehler and P. Meil (eds.), Technology and Work in German Industry. London, New York: Routledge, 342-358.

Shavit, Y., Arum, R. and Gamoran, A. with Menahem, G. (eds.) (2007), Stratification in Higher Education: A Comparative Study. Stanford, California: Stanford University Press.

Silva, O. (2007). The Jack-of-all-trades entrepreneur: innate talent or acquired skill?, Economics Letters, 97, 3, 118-123.

Stone, K.V.W. (2006). Thinking and Doing: The Regulation of Workers' Human Capital in the United States, Socio-Economic Review, 4, 121-38.

Trow, M. (2000), From Mass Higher Education to Universal Access: the American Advantage, Minerva, 37/4, 303-328.

Van Dijk, J. (2005). The Deepening Divide. Inequality in the Information Society. London: Sage Publications.

Van der Velden, R. \& M. Wolbers (2003), The Integration of Young People into the Labour Market: The Role of Training Systems and Labour Market Regulation, In: W. Mülller \& M. Gangl (eds.), 
Transitions from Education to Work in Europe. The Integration of Youth into EU Labour Markets, Oxford: Oxford University Press, 186-211.

Venkataraman, S. (1997). The distinctive domain of entrepreneurship research: An editor's perspective. In J. Katz and R. Brockhaus (eds.), Advances in entrepreneurship, firm emergence and growth: Vol. 3, Greenwich, CT: JAI Press, 119-138.

Verluyten, P. (2001). Intercultural Communication in Business and Organisations. An Introduction. Leuven, Leusden, London: Acco.

Wagner, J. (2003). Testing Lazear's Jack-of-all-trades view of entrepreneurship with German microdata, Applied Economics Letters, 10, 11, 687-689.

Wagner, J. (2006). Are nascent entrepreneurs Jacks-of-all-trades? A test of Lazear's theory of entrepreneurship with German microdata, Applied Economics, 38, 2415-2419.

Weimer, S. (1992). Small Firms in Big Subcontracting. In: N. Altmann, C. Koehler and P. Meil (eds.), Technology and Work in German Industry. London, New York: Routledge, 313-322.

Weinert, F.E. (2001). Concept of Competence: A Conceptual Clarification. In D.S. Rychen and L.H. Salganik (eds.), Defining and Selecting Key Competencies. Göttinge: Hogrefe and Huber, 45-66.

Wickramasinghe, N. and Von Lubitz, D. (2007). Knowledge-Based Enterprise. Theories and Fundamentals. Hershey: IGI Publishing.

Wiliam, D. (2010). The Role of Formative Assessment in Effective Learning Environments. In: OECD, The Nature of Learning: Using Research to Inspire Practice. Paris: OECD Publishing.

Williams, K., Cutler, T., Williams, J. and Haslam, C. (1987). The end of mass production?, Economy and Society, 16, 3, 405-439. 